\title{
Arbetarkollektivet i dag - ny studie och teoretisk utveckling
}

\author{
Jonas Axelsson, Jan Ch. Karlsson \& Egil J. Skorstad
}

SAMMANDRAG: Sverre Lysgaards teori om arbetarkollektivet är fortfarande en inflytelserik klassiker inom skandinavisk arbetslivsforskning. Lysgaards studie genomfördes i en massaoch pappersfabrik på 1950-talet och Jonas Axelsson, Jan Ch. Karlsson och Egil J. Skorstad har nu återvänt till fabriken för att ta reda på vad som hänt med arbetarkollektivet sedan dess. Genom observationer på arbetsplatsen och intervjuer med arbetare, ingenjörer och chefer, i tillägg till att de har haft tillgång till data från 1950-talet och 1980-talet, kan författarna kartlägga den teknologiska och arbetsorganisatoriska utvecklingen och dess påverkan på arbetarkollektivet. Utifrån denna analys föreslår de två förändringar i Lysgaards teori. Den ena är att dela upp det han omtalar som det "tekniskt-ekonomiska systemet" i två relativt autonoma system, det tekniska och det ekonomiska. Det andra är att analysera hur kollektivet har infiltrerat det tekniska, men inte det ekonomiska systemet.

NYCKELORD: Sverre Lysgaard; arbetarkollektivet; tekniskt system; ekonomiskt system; mänskligt system; kollektivsystem.

PUBLICERINGSHISTORIK: Översättning av artikeln "Arbeiderkollektivet i dag - replikasjon og teoretisk utvikling" i Tidsskrift for samfunnsforskning, volym 57, nr 22016 (DOI: https://doi.org/IO.I826I/issn.I504-29IX-2016-O2-OI).

JONAS AXELSSON är lektor i arbetsvetenskap vid Karlstads universitet.

E-POSTADRESS: jonas.axelsson@kau.se

JAN CH. KARLSSON är professor i sociologi och arbetsvetenskap vid Karlstads universitet. E-POSTADRESS: jan.karlsson@kau.se

EGIL J. SKORSTAD är professor emeritus vid Høgskolen i Østfold.

E-POSTADRESs: egil.j.skorstad@hiof.no

FÖRSLAG PÅ KÄLLANGIVELSE:

Axelsson, Jonas, Jan Ch. Karlsson \& Egil J. Skorstad (2019) "Arbetarkollektivet i dag - ny studie och teoretisk utveckling", i Arkiv. Tidskrift för sambällsanalys, nr IO, s. II3-I43. DOI: https://doi.org/I0.I3068/2000-6217.10.5

(C) original: författarna/Tidsskrift for samfunnsforskning, Universitetsforlaget AS 2016

(C) svensk version: författarna/Arkiv förlag \& tidskrift 2019 (publicerad 28 maj 2019)

Artikeln distribueras enligt en upphovsrättslicens från Creative Commons:

Erkännande-Ickekommersiell-IngaBearbetningar 3.0 Unported, som medger fri ickekommersiell användning och spridning i oförändrat skick så länge källan anges. 
Arkiv. Tidskrift för samhällsanalys är en sakkunniggranskad vetenskaplig tidskrift för samhällsvetenskap och historia. Samtliga artiklar publiceras fritt tillgängliga på:

$$
\text { www.tidskriftenarkiv.se }
$$

Beständig länk, DOI: https://doi.org/IO.13068/2000-62I7

Den här artikeln finns tillgänglig i följande format:

PDF: via beständig länk, DoI: https://doi.org/IO.I3068/2000-6217.IO.5

TRYCK: ingår i bokutgåva av numret, ISBN: 978 9I 79243272

Grafisk utformning och sidnumrering är identisk i pdf och tryck.

Samtliga artiklar i nr ıo (2019) nås via beständig länk, DOI: https://doi.org/IO.I3068/2000-6217.10

Arkiv. Tidskrift för sambällsanalys

ISSN: 2000-6217 (för elektronisk resurs)

ISSN: 2000-6225 (för tryckta nummer)

ges ut av

Stiftelsen Arkiv för främjande och spridning av samhällsvetenskaplig och historisk forskning

genom

Arkiv förlag \& tidskrift

Box 1559

SE-22I OI Lund

BESÖK: L Gråbrödersg 3 c, ipg

TEL: 046-I3 3920

ARKIV FÖRLAG: arkiv@arkiv.nu·www.arkiv.nu

TIDSKRIFTEN ARKIV: red@tidskriftenarkiv.se.www.tidskriftenarkiv.se

ANSVARIg UTGIVARE \& CHEFREDAKTÖR: Sven Hort

AdMinistrativ Redaktör: David Lindberg

Redaktörer: Paavo Bergman, Per Dannefjord, Lisa Kings,

Zhanna Kravchenko, Anna-Maria Sarstrand Marekovic 


\title{
Arbetarkollektivet i dag \\ - ny studie och teoretisk utveckling
}

\author{
JONAS AXELSSON, JAN CH. KARLSSON \\ \& EGIL J. SKORSTAD
}

Boken Arbeiderkollektivet. En studie i de underordnedes sosiologi av Sverre Lysgaard (200I [196I]) har sedan länge status som en enastående klassiker inom skandinavisk arbetssociologi och arbetslivsforskning generellt. Titeln är identisk med det fenomen som beskrivs i boken och som handlar om en gemenskap bland anställda som befinner sig längst ned i ett företags hierarki i verksamheter i vilka jakten på effektivitet och lönsamhet är ett överordnat värde. Gemenskapen - eller den informella organisationen arbetarkollektivet - fungerar som en motvikt mot denna jakt och beskyddar den enskilda anställda mot det som måste uppfattas som orimliga och obönhörliga krav. Arbetarnas sammanhållning bidrar till att de enskilda medlemmarna får både ära och makt. Där sammanhållningen är stark står vi inför ett mäktigt och effektivt kollektiv; där den är svag blir kollektivet på motsvarande sätt vanmäktigt.

Lysgaards analys baserar sig på att det finns en motsättning mellan företaget på den ena sidan och de underordnade arbetarna på den andra. I sin undersökning tar han utgångspunkt i en systemanalys där det tekniskt-ekonomiska systemet (företaget), det mänskliga systemet

Artikeln har skrivits inom projektet "Kulturbrytningar i arbetsorganisationer - en studie med utgångspunkt i Lysgaards teori om arbetarkollektivet", finansierat av Forte, forskningsrådet för hälsa, arbetsliv och välfärd, och publicerades ursprungligen som "Arbeiderkollektivet i dag - replikasjon og teoretisk utvikling" i Tidsskrift for samfunnsforskning, volym 57, nr 2 (2016). 
och kollektivsystemet utgör tre huvudkomponenter, varvid det är motsättningarna mellan de två första systemen som bidrar till att kollektivet utvecklar sig och finner sin form. I boken återger Lysgaard en rad exempel på hur detta motsättningsförhållande artar sig och skapar betingelser för denna utveckling. Många exempel präglas naturligt nog av att vi befinner oss i en annan tid - mitten av 1950-talet - där skillnader och motsättningar var mer uppenbara än de kan förefalla i dag. Frågan blir då om den tid som har gått har bidragit till att dessa betingelser har ändrats, så att de kan tänkas ha rubbat Lysgaards teori. För att försöka svara på den frågan har vi återvänt till samma fabrik som han och hans kollegor besökte för mer än 60 år sedan. Mot bakgrund av denna nya studie föreslår vi i det följande att teorin kan utvecklas enligt två argumentationskedjor (Karlsson \& Bergman 2017, kapitel 7). Den ena går ut på att det tekniskt-ekonomiska systemet analytiskt kan delas upp i sina beståndsdelar: det tekniska systemet och det ekonomiska systemet. Den andra argumentationskedjan innebär att det inte bara är på det sättet att det tekniskt-ekonomiska systemet kan infiltrera kollektivsystemet (vilket Lysgaard postulerade), men också att kollektivet kan infiltrera det tekniska systemet (vilket han menade var omöjligt). Teoretiskt kan man naturligtvis även föreställa sig att det också infiltrerar det ekonomiska systemet, men vi har inga empiriska indikationer på att så skedde.

\section{Huvuddragen i Lysgaards teori}

När Lysgaard ska förklara varför arbetarkollektivet uppstår tar han som nämnt sin utgångspunkt i två system som står i motsättning till varandra. Å ena sidan opererar han med det tekniskt-ekonomiska systemet, det vill säga företaget, som präglas av att det ställer ensidiga, omättliga och obönhörliga krav på de anställda som befinner sig nederst i hierarkin. Kraven är ensidiga i den meningen att de uteslutande rör sig om bidrag som kan leda till ökad effektivitet. De är omättliga på det sättet att systemet aldrig får nog; det krävs alltid mer av samma saker: ökad arbetsinsats, högre effektivitet, mer rationalitet. Och de är obönhörliga eftersom den som inte räcker till kan bli utbytt mot andra (eller något annat) som är effektivare. $\AA$ andra sidan opererar han med det mänskliga systemet, det 
vill säga de underordnade som kännetecknas av helt motsatta krav och behov. För det första är de inte ensidiga utan mångsidiga i det avseendet att de även har förmågor och intressen utöver det som strängt taget behövs för att kunna utföra arbetet. För det andra är de begränsade på det sättet att det finns inskränkningar i hur hårt de kan jobba, hur tunga lyft de kan göra, hur intensivt de kan arbeta och hur länge de kan hålla på innan de måste ta paus. Och för det tredje vill de gärna ha det tryggt och inte behöva leva med den osäkerhet som ligger i faran att kunna bli utbytt mot någon annan.

I detta motsättningsfyllda förhållande uppstår behovet av beskydd och det är detta beskydd som så att säga är arbetarkollektivets funktion. Det fungerar som en buffert som avskärmar de underordnade mot företagets ensidiga, omättliga och obönhörliga krav, och som leder till att det som annars skulle ha varit särdeles vanskligt kan bli lättare att uthärda dagligdags. Beskyddet är å sin sida förankrat i normer för hur man ska uppträda och förstå sin egen situation, vilket blir själva definitionen av vad arbetarkollektivet rör sig om. Om normerna är tydliga och accepterade av alla underordnade, så står vi inför ett mäktigt kollektiv som effektivt kan beskydda sina medlemmar. Är de oklara och omstridda, så är kollektivet motsvarande svagt och medlemmarna var för sig sårbara. Det mäktiga kollektivet förutsätter alltså samstämmighet och vilja att ge avkall på den slags individuella frihet som en gemenskap har svårt att acceptera. Det vanmäktiga kollektivet är å sin sida ett resultat av att det är fritt fram för alla; en situation där allt är tillåtet eller riktigt, oberoende av vad man tycker eller kan hitta på att göra.

Lysgaard visar oss också hur dessa normer utvecklas och upprätthålls över tid. De uppstår varken planmässigt eller slumpmässigt, säger han (200I, s. 2II), det tar tid innan de kan utvecklas och få fäste så att de lämpar sig för att reglera folks uppförande. Dessutom utvecklas de inte överallt, utan det finns tre avgörande förutsättningar som måste existera för att de ska kunna uppstå. För det första måste det finnas en formellt planlagd organisation som präglas av lönsamhet och effektivitet, det vill säga ett tekniskt-ekonomiskt system. För det andra måste det föreligga ett anställningsförhållande som innebär en eller annan form av beroende. Och för de tredje måste det finnas en hierarki där företagets krav 
bärs upp av "företagets folk", det vill säga de som befinner sig i organisationspyramidens översta skikt.

Givet sådana förutsättningar kan arbetarkollektivet utvecklas och ta form. Detta sker enligt Lysgaard (200I, s. I44-I49) genom en gemensam problemtolkning och spontanorganiserade processer. Spontanorganiseringen är ett resultat av att underordnade möts när de arbetar tillsammans och upptäcker att de har något gemensamt som förenar dem och skiljer dem från andra. I första omgången kan det vara begränsat till synliga särdrag som arbetsuppgifter, position, uppförande och kläder. Även om flera av dessa drag kan framtona som triviala kan de likafullt vara tillräckligt viktiga för att de som träffas ska kunna identifiera sig med varandra. Efter hand kan de så fördjupa relationen i den meningen att de diskuterar sin egen situation, prövar att ta reda på vad som utmärker dem, vad som är rimligt och orimligt, rättfärdigt och orättfärdigt, vem som har ansvar för det som gick fel och vem som bör få äran för det som kan uppfattas som positivt. Det är genom dessa processer - interaktionen, identifieringen och problemtolkningen - som normerna uppstår och bildar det som blir klassificerat som arbetarkollektivet. Genom samtalen utformas och bekräftas gemensamma regler som de som vill bli accepterade måste förhålla sig till och följa. De som inte bryr sig blir straffade. Där det finns ett kollektiv, säger Lysgaard (200I, s. 8I), slipper ingen arbetare undan; alla underordnade är "medlemmar" antingen de är det $\mathrm{i}$ en aktiv, passiv eller oppositionell mening.

Han ger också uttryck för att dessa normer - om de blir starka och tydliga nog - kan börja leva sitt eget liv, oberoende av de betingelser som gjorde att de uppstod över huvud taget. I så fall ger de vägledning för vem du bör umgås med, vem du ska identifiera dig med och hur du ska förstå din egen situation. Orsaksrelationen vänds alltså så att säga upp och ned. Det som ursprungligen kunde betraktas som orsaker till att kollektivet uppstod, kan nu förstås som resultat av dess funktion. Ensidiga relationer förvandlas till ömsesidiga relationer och det uppstår i bästa fall en självbärande process: arbetarkollektivet upprätthåller eller reproducerar sig självt. Lysgaard tillägger emellertid att detta inte nödvändigtvis är något som alltid kommer att ske. Tolkningarna kan inte, säger han (200I, s. 22), baseras på tunn luft, det måste finnas ett eller 
annat som de kan förankras i och som gör dem sannolika - något som därmed blir avgörande för om kollektivet i sin tur blir starkt eller svagt. I förlängningen av detta resonemang ligger det också att ett starkt kollektiv, paradoxalt nog, kan försvaga sig självt genom de förbättringar det kan uppnå på basis av sin styrka.

\section{Metod}

För att söka svar på frågan vad som skett med arbetarkollektivet sedan Lysgaards dagar har vi återvänt till samma fabrik - Peterson \& Sønn i Moss, i Norge - där han och hans forskargrupp genomförde sin studie på 1950-talet. Vi har alltså utfört en historisk komparativ fallstudie (Ackroyd \& Karlsson 20I4) i form av en upprepning av hans undersökning. Datainsamlingen pågick från 2009 till och med 2012. På sin tid hade Lysgaard och fyra intervjuare full tillgång till arbetsplatsen och alla arbetade en eller ett par veckor på olika avdelningar, deltog i möten med mera. De genomförde också drygt 250 intervjuer, huvudsakligen med arbetare men även med administratörer och chefer.

Vår grupp har inte haft tillräckliga resurser för att följa upp undersökningen i motsvarande omfattning - och eftersom vi inte har de kvalifikationer som i dag krävs för att köra den automatiserade processen har vi inte heller kunnat arbeta i den moderna fabriken. Vi har emellertid blivit bemötta med samma positiva attityd som Lysgaards forskargrupp erfor på sin tid. Vi har haft fri tillgång till fabriken och med hjälp av den lokala fackföreningen och personalavdelningen har vi avtalat tid för intervjuer med anställda. Vi har genomfört I28 intervjuer, huvudsakligen med arbetare (IO2 intervjuer), men också med förmän, ingenjörer, chefer på olika nivåer och representanter för fackföreningen. Intervjuerna bygger på den intervjuguide som Lysgaard publicerade (200I, appendix), men vi har ändrat och utvidgat den en del. Intervjuerna spelades in på band och transkriberades ordagrant. Vi har analyserat data i överensstämmelse med etablerade och accepterade kodningstekniker genom att forma koder och relationer mellan dem (Maxwell 2012; Saldaña 2013). $\AA$ ena sidan har vi hämtat koder och kategorier från Lysgaards teori, exempelvis "tekniskt-ekonomiskt system", "kollektiv" och "infiltration"; 
å andra sidan har vi också genererat koder från våra egna data, såsom "avgränsat", "kvantitetsorientering" och "medgörlig". Vår diskussion täcker perioden fram till våren 20I2, då fabriken lades ned, men själva intervjuandet har pågått även efter den tidpunkten.

I tillägg har vi data från en studie av fabriken från första halvan av I980-talet (Skorstad 1987). Dessa data är baserade på observationer, dokument och intervjuer med ett stort antal arbetare, chefer, produktionsingenjörer, samt pensionerade arbetare som var anställda under den period som Lysgaard befann sig på fabriken. Vi har därför även kunnat beskriva produktionsprocessens egenart såväl på 1950- som på 1980-talet, liksom arbetarnas motstånd på arbetsplatsen - främst i form av produktionsbegränsningar. I tidigare publikationer har vi koncentrerat oss på empiriska analyser av utvecklingen på fabriken under dessa decennier (Karlsson, Skorstad \& Axelsson 2015), utvecklingen av arbetarkollektivets motståndsformer (Karlsson \& Skorstad 2019), samt jämfört Lysgaards teori med nyare och motsvarande anglosaxiska studier (Karlsson 20I5; Skorstad \& Karlsson 20I7). I den här artikeln koncentrerar vi oss på möjligheten att utveckla själva teorin mot bakgrund av dessa analyser. Den fullständiga rapporten från projektet är boken Collective mobilization in changing conditions (Axelsson, Karlsson \& Skorstad 20I9).

\section{Utvecklingen av produktionsteknologi och ägande i fabriken}

Den fabrik som Lysgaard och hans kollegor kom till i mitten av I950-talet var ett pappersproducerande företag. Den var dessutom en så kallad integrerad fabrik i den meningen att den förutom papper också framställde massa till eget bruk, något som på grund av processteknologiska orsaker inte var vanligt på den tiden (Skorstad 2002). Då fabriken lades ned 2012 fungerade den fortfarande som en integrerad enhet, men nu på ett helt annat sätt än den gjorde på 1950-talet. Ursprungligen försiggick till exempel framställningen av massa i en satsvis form på det sättet att stora kokare fylldes med flis och tillslöts manuellt, varefter kemikalier och ånga tillsattes. Denna blandning kokades sedan i ett visst antal timmar (I95I i cirka fyra timmar) innan varje kokare tömdes, rengjordes och ställdes 
i ordning för nästa kok. Kokt massa fördes vidare till tvättning, silning, blekning och torkning innan den gick vidare till den slutliga bearbetningen till färdig produkt i pappersmaskinerna. Under tvättningsfasen omedelbart efter kokningen skildes kemikalierna ut från massan och återvanns i en egen process så att de kunde användas på nytt.

Detta satsvisa sätt att operera på var i väsentlig grad med på att forma arbetsvillkoren i produktionen. Under kokningsfasen ledde det exempelvis till att arbetsinsatsen var som mest krävande och intensiv innan uppstarten och efter avslutningen av ett kok. Detta betydde också att själva kokningsperioden fungerade som ett slags andrum mellan de slitsamma passen. I övrigt fanns andra avsnitt där arbetet kunde vara direkt farligt, så som lutkokeri och sodahus eller bullrande som sileriet. Arbetsinsatsen präglades på detta sätt i hög grad av att vara manuell, riskfylld och slitsam, även om det rörde sig om processproduktion där själva bearbetningen för det mesta skedde i slutna system med hjälp av kemiska reaktioner och reglering av temperatur och tryck. Processtyrningen försiggick på grundlag av den information arbetarna skaffade sig genom att kontrollera diverse mätinstrument och genom att lyssna, känna, lukta och se. Det att ha tillräcklig insikt i samspelet mellan produktionsutrustning och processförlopp var därför en avgörande förutsättning för att uppnå optimal drift. Det var exempelvis viktigt att kunna bedöma vilka belastningar tryckregleringar kunde ha på utrustningen.

Från början av 1970-talet och framåt gjordes investeringar och förändringar som gradvis resulterade i en ny produktionsform. En av de viktigaste omställningarna genomfördes I97I i och med att man under detta år övergick från satsvis till kontinuerlig massakokning. För arbetarna representerade detta en kraftig förbättring, först och främst för att den direkta kopplingen mellan produktionsmängd och arbetsinsats bröts. En ökad mängd kunde från och med nu helt enkelt uppnås genom att öka hastigheten på en inmatningsskruv kopplad till den kontinuerliga kokaren. Ökad produktion var alltså inte längre liktydig med mer slit. Härigenom försvann också grunden för en central stridsfråga som hade präglat förhållandet mellan överordnade och underordnade $\mathrm{i}$ alla år, nämligen frågan om hur många kok som borde produceras under varje skift (Skorstad 2002). 
Den andra viktiga förändringen handlade om att processen genomgick en gradvis och tilltagande automatisering. I praktiken gick denna ut på att allt fler kontrollslingor lades in i processen, att egna kontrollrum inrättades med den styrteknologi som hörde till och att arbetarna drogs bort från maskinerna i fysisk mening. Med detta gick processtyrningen också över från att vara baserad på direkta och omedelbara sinnesintryck till att utföras indirekt via dataskärmar som visade flytscheman och värden på kritiska variabler. Som ett resultat av detta arbete var produktionen vid avvecklingen 2012 nästan fullständigt automatiserad. Parallellt med denna automatisering knöts de olika faserna även tätare samman jämfört med hur det varit på I950-talet. Processen utvecklades alltså från att vara ett löst kopplat till ett tätare kopplat system, och därmed också till ett system som blev mer sårbart när det gäller störningar som kunde fortplanta sig från en fas till en annan (Perrow 1999; Skorstad 1987). För produktionsarbetarna betydde allt detta att arbetet blev lättare i fysisk mening, behagligare under normal drift och mer hektiskt och besvärligt när det då och då kunde uppstå oförutsedda störningar. Genom dessa omställningar ändrades också kvalifikationskraven fullständigt. I och med att produktionen totalt sett framträdde i en mer integrerad och komplex form förutsatte realiseringen av optimal drift mer omfattande kvalifikationer än de som varit nödvändiga tidigare.

Arbetsvillkoren i produktionen präglades naturligtvis även av förhållandet till ledningen, vilket hos Lysgaard framstår som en motsättningsfylld affär och en källa till den kollektiva sammanhållningen han registrerade i fabriken. Detta var motsättningar som bestod under de efterföljande åren, bland annat genom den fortlöpande motsättningen om vad som var ett passande antal kok. Från 1980-talet och framåt verkar det emellertid som att det inträdde en förändrad stämning i fabriken, vilket vi har beskrivit i andra sammanhang (Karlsson, Skorstad \& Axelsson 2015).

Enligt en rapport från en tidigare produktionsarbetare får vi också veta att "miljön präglades av en ömsesidig respekt" (Grønna 20I4, s. 84), vilket stämmer rimligt väl med de svar vi fick i våra egna intervjuer. 2006 skedde emellertid ett ägarskifte som skakade fundamentet för den ömsesidiga respekten. Det året såldes företaget till nya ägare och därmed 
introducerades också en ny ledarstil där arbetarna följdes upp och kontrollerades tätare, hindrades från att få tillgång till viktig information och utestängdes från beslutsarenor som var knutna till den operativa driften. Samtidigt representerade detta början på en praktik i vilken de nya ägarna agerade helt utifrån egna prioriteringar, ibland i strid med formaliserade avtal och procedurer. Allt detta bidrog snabbt till att de fick tillnamnet "cowboyerna", ett uttryck som signalerade att det gamla tillitsförhållandet hade försvunnit. Efter sex år med denna driftsform var det slut. Företaget gick i konkurs och all produktion upphörde 2012.

\section{Det tekniska och det ekonomiska systemet}

Den ena utvecklingslinjen av teorin om arbetarkollektivet som vi föreslår är att dela upp det tekniskt-ekonomiska systemet i två olika system. Lysgaards systembegrepp är ganska enkelt: Han argumenterar för att vart och ett av de system han behandlar består av två andra system, nämligen ett värdesystem och ett rollsystem. Hans resonemang utöver detta går allmänt sett ut på att begreppet är en abstraktion. Vi håller oss också på denna nivå när det gäller användningen av begreppet.

Lysgaard genomför heller inte någon detaljerad analys av det teknisktekonomiska systemet som teoretisk enhet. Han avstår helt medvetet från detta till förmån för analysen av arbetarkollektivets struktur, mekanismer och processer. "Vi ska”, säger han, "koncentrera oss på kollektivsystemet" (200I, s. 82) och "Tanken är hela tiden att behandlingen [av det teknisktekonomiska systemet] ska tjäna till att belysa kollektivsystemet" (200I, s. I23). Det tekniskt-ekonomiska systemet utgör främst kollektivsystemets kontext och konkurrent om de underordnade arbetarnas identitet. I analysen framhåller han att det innehåller en uppsättning normer och värden som betonar företagets effektivitet och lönsamhet samt ett formellt system av befattningar för att uppnå dessa värden. Det medför att det $\mathrm{i}$ det tekniskt-ekonomiska systemet ligger att det ställer krav på anställda som karaktäriseras av de tre saker vi nämnt: Det är omättligt, ensidigt och obönhörligt. Mycket mer får vi inte veta. Ingenstans diskuterar Lysgaard varför han valt termen det "tekniskt-ekonomiska systemet" eller hur de två komponenterna kan tänkas förhålla sig till varandra. 
Frånvaron av en närmare diskussion hos Lysgaard kring de två komponenterna i det tekniskt-ekonomiska systemet leder oss till att undersöka vad som händer med teorin om vi delar det i två skilda system, ett tekniskt och ett ekonomiskt. Det handlar därvid inte om två helt separata och oberoende system, inte heller om att det ena förutbestämmer det andra (teknisk determinism respektive ekonomisk determinism). I stället utgår vi från att de båda systemen har en relativ autonomi i förhållande till varandra. Vi finner då att Lysgaards beskrivning av det teknisktekonomiska systemet som inriktat på effektivitet, lönsamhet och att arrangera en befattningsstruktur egentligen hör till det ekonomiska systemet. Eftersom de underordnade arbetarna i våra intervjuer i första hand diskuterar i relation till det tekniska systemet i samband med vad som skett på fabriken koncentrerar vi oss på detta. Vi kan med Blauner (1964, s. 6) definiera teknologi som

alla de fysiska objekt och tekniska procedurer (både manuella och automatiska) som regelbundet används inom en näringsgren för att producera varor och tjänster. Teknik betecknar i första hand maskinsystemet, graden och typen av mekanisering, men inkluderar även den tekniska kunskap och de mekaniska färdigheter som krävs i produktionen.

(Det förhållandet att begreppsbestämningen av teknologi inkluderar kunskap kommer att få betydelse för vår argumentation i nästa avsnitt.) När vi nu gör en uppdelning mellan tekniskt och ekonomiskt system så finner vi att Lysgaards kännetecken för det tekniskt-ekonomiska systemet, det vill säga att det är omättligt, ensidigt och obönhörligt, snarare gäller det ekonomiska systemet än det tekniska. Med inspiration från det sätt på vilket Lysgaard använder dessa termer vill vi benämna det tekniska systemet som avgränsat, flersidigt och medgörligt. Vi ska nu gå igenom dessa tre karaktäristika i tur och ordning och därefter specificera ytterligare en roll som den underordnade arbetaren har, denna gång $\mathrm{i}$ relation till det tekniska systemet.

Med avgränsat menar vi att det relativt autonoma tekniska systemet visserligen kräver mycket av de arbetande vad gäller arbetsinsats, tid och så vidare, men det kräver inte hur mycket som helst. I jämförelse med det ekonomiska systemets omättlighet kan det tekniska systemet till- 
fredsställas: Tekniska processer verkar präglas av att en välavvägd arbetsinsats är avgörande. För en fungerande teknisk process är både "underarbete" och "överarbete" ödeläggande. Skapande av hög kvalitet kräver att den som använder tekniken har insikt om när bearbetningen av ett objekt ska upphöra - en kunskap om när något är färdigproducerat. Detta förhållande var tydligt i fabriken i Moss. Exempelvis berättar en arbetare en episod om kaustiseringsgradens betydelse, och de inneboende begränsningar man måste ta hänsyn till om man vill ha god kvalitet på cellulosamassan. Utan att vi går in på de tekniska termernas innebörd, är utgångspunkten den här (vår emfas):

Ju högre kaustiseringsgrad, desto högre effektivt alkaliskt - alltså mer effektiv koklut och det handlar om en massa pengar, upp till en punkt. Om du går över den punkten får du en övermättning av kemikalier. Det blir "grönkörning" som vi kallade det, då stoppade allt upp och blev där i flera dagar [da gikk alt i bøtta og ble der i flere dager].

Vid ett tillfälle kommer en hög chef och kräver att operatören ska gå över den punkten, men han vägrar och säger att det får i så fall förmannen avgöra. Chefen vänder sig då till förmannen, som går med på kravet. "Jag svarar att det blir grönt. - 'Ja, jo, men upp med kalken!' Så blev det till att vi gjorde det. Och det blev grönt." Det som beskrivs i den här episoden är att chefen, som företrädare för det ekonomiska systemet, på omättligt sätt vill pressa processen mer än vad som är tekniskt lämpligt. Ledningen kan inte acceptera det mättliga och relativt begränsade hos teknologin - och i intervjumaterialet finns många liknande berättelser som den om grönkörningen som vittnar om detta.

En viktig aspekt vid att skilja mellan det omättliga och det avgränsade utgjordes därför av en distinktion mellan kvantitetsorientering och kvalitetsorientering. Vi ser härvidlag en påtaglig skillnad mellan det tekniska och det ekonomiska systemet. Om det ekonomiska systemet präglas av en kvantitativ maximering så karaktäriseras det tekniska systemet av en kvalitativ optimering. Medan det finns både en undre och en övre gräns för vad som leder till god kvalitet så finns det inga övre gränser för ekonomisk vinst. Teknologisk utrustning i sig, och teknologiska processer i sig, har inbyggda mått för vad som är en optimal användning av 
utrustning respektive en optimal teknologisk process. Men ett kapitalistiskt företag kan inte gå med för mycket vinst eller vara för framgångsrikt på marknaden. (På samhälleligt, makroekonomiskt plan finns problem med "överhettning", men något liknande tycks inte gälla enskilda företag.) Det ekonomiska systemet kan tolkas som inriktat på större kvantiteter - större produktionsvolymer, högre vinster - och i och med detta skapas omättlighet. Det tekniska systemet kan däremot ses som orienterat mot kvalitet. Kvalitetsskapande tar naturligtvis mycket mänsklig kraft i anspråk, men teknologin i sig har begränsningar som gör att den inte kan pressas hur mycket som helst - det tekniska systemet är därför avgränsat även om det inte är kravlöst. Detta innebär emellertid inte att vi betraktar teknik som helt oberoende av ekonomi. Det är väl belagt att val av teknik påverkas av ekonomiska förhållanden och att teknik generellt är "villkorad av balansen mellan sociala krafter" (Bélanger 2006, s. 340 ).

Konflikten mellan det ekonomiska och det tekniska systemet leder också till att "karlarna på golvet" kan respektera de överordnade representanterna för det tekniska systemet på helt annat sätt än representanterna för det ekonomiska systemet. De senare - och i synnerhet cowboyerna blev ofta kritiserade för bristande hänsyn till tekniska realiteter och nödvändigheten av att optimera driften. Ingenjörerna, som tillhörde det tekniska systemet, nämndes däremot ofta med respekt, särskilt under senare år (vi återkommer i nästa avsnitt till skäl för detta). Några exempel:

Han den siste processingenjören vi hade uppe i sodahuset, han var ung, men var en väldigt all right kille. Om du hade problem och han inte helt förstod vad det handlade om, så var han inte sådan som bara bestämde. Han var hellre med på att lösa det problemet.

Driftsproblem, då ringde vi gärna till driftsingenjören. Det var flera gånger att vi kände att vi inte kom längre och då ringde vi och konfererade med driftsingenjören. Det var helt accepterat.

De här optimeringsåtgärderna vi höll på med, det var ett väldigt samarbete med driftsingenjören. [...] Det var en del av kulturen, kan du säga. Vi införde relativt fort det vi efter hand kallade for fiber-forum, där alla operatörerna blev inbjudna tillsammans med driftsingenjören, det var väl han som bjöd in. Och i de här mötena så skapade vi instruktioner och gemensamma regler. Så vi kände hela 
tiden att vi var med på att utveckla det här, det var inte något som blev trätt ned över huvudet på oss.

I de historier som var i svang bland arbetarna kunde ingenjörer till och med framstå som hjältar. En av arbetarna har i minnen från fabriken (Grønna 20I4, s. 64) berättat hur en av ingenjörerna, Sverre, blev indragen i något som framstår som en direkt konflikt mellan ekonomiskt och tekniskt system eller med andra ord en motsättning mellan kvantitetsinriktning och kvalitetsinriktning. Det rörde sig om en strid om olika slags flis för massakokning, där ledningen köpt in undermålig flis av ekonomiska skäl:

Fliskvaliteten kunde variera från minut till minut, och det var omöjligt att producera jämn kvalitet över tid. Företagsledningen skyllde hela tiden på brist på plats. Sverre såg tidigt det här flisproblemet, och försökte på olika sätt prata ledningen till rätta. En dag när flisen var helt hopplös och på gränsen till rutten, tog han ett stort fång med flis in till chefen för flisinköpen. Han slängde ut flisen på skrivbordet och sa: ”Det går inte an att göra massa av sådan här flis!” Så gick han, medan flischefen måste städa skrivbordet sitt själv.

Innan vi lämnar diskussionen om det avgränsade hos det tekniska systemet bör vi notera att vi här kan se en likhet med det mänskliga systemet. Det är inte bara människor som har en inbyggd gräns för hur mycket som kan presteras - det finns också inbyggda begränsningar i teknologin.

Om vi så går vidare till begreppet flersidighet, så vill vi betona det öppna i det tekniska systemet. Dess karaktär kan skifta beroende på kopplingar till de andra systemen - det ekonomiska systemet, det mänskliga systemet och kollektivsystemet. Den arbetsdelning och de befattningar som existerar vid en given tidpunkt i fabrikens historia är inte den enda tänkbara utifrån det tekniska systemets potentialer. Exempelvis genomfördes flera omorganisationer under cowboyernas tid utan att det tekniska systemet förändrades. I stället låg ekonomiska motiv bakom det förhållandet att enskilda befattningar avskaffades och nya infördes. Under en period introducerades till exempel förmansassistenter, men efter en tid bedömde ledningen att dessa befattningar inte fungerade särskilt bra. De gjordes därför om till produktionsledare, men även dessa befattningar avvecklades. Skiftledarna döptes å sin sida om till gruppkoordinatorer. Samtidigt skulle de fungera som maskinförare och efter hand förflyttades 
de till dagtid med ansvar för en hel avdelning. Det fanns också exempel på att uppgifter som tidigare hade utförts av olika operatörer blev omdefinierade till en enda befattning, varigenom ansvarsområdet utvidgades. Ibland möttes emellertid sådana åtgärder av motstånd:

De [ledningen] försökte ta bort en befattning och lägga ihop det jobbet med ett annat jobb. Men då visste vi hur omfattande det jobbet var och hur stort det andra jobbet skulle bli om en person skulle köra alltihop. Och jag säger alltså, "Så kan vi inte ha det, det äventyrar säkerheten", och det fick vi genomslag för. Det är begränsat hur stort anlägg du kan köra.

Det flersidiga i det tekniska systemet kan på detta sätt ses som en mellanposition mellan det ensidiga i det tekniska systemet och det mångsidiga i det mänskliga systemet. Å ena sidan är det tekniska systemet öppnare och mer formbart än fabrikens ekonomiska system. A andra sidan vill vi betona den begränsade komplexiteten i det tekniska systemet om vi jämför det med det mänskliga systemet, det vill säga människorna själva och deras behov och kapaciteter.

Ser vi på det sista centrala kännetecknet hos det tekniska systemet, så har vi valt att använda uttrycket medgörlig - i betydelsen eftergiven inom bestämda gränser. Det tekniska systemet är på flera sätt medgörligt snarare än obönhörligt som det ekonomiska systemet, även om olika teknologi förutsätter skilda kunskaps- och färdighetsformer hos de som ska sköta den. Det krävs både kroppslig och mental energi för att hantera olika steg i processen i massa- och pappersfabriken. Under vissa faser ställs det bland annat krav på att stå ut med monotona arbetsuppgifter, under andra faser fordras intellektuella och analytiska förmågor (jfr Zuboffs I988 analyser av sådana fabriker). Medan fabrikens tekniska system på Lysgaards tid var arbetsintensivt och styrt på basis av information som operatörerna fick genom att lyssna, känna, se och lukta, handlade det efter hand om en stadigt mer teknologiintensiv process där styrningen skedde utifrån information som förmedlades via dataskärmar. Skilda teknologiska lösningar kräver alltså olika kvalifikationer hos arbetarna. Samtidigt sker detta inom ganska vida ramar, det vill säga att fördelningen av kunskaper och färdigheter bland operatörerna kan variera väsentligt. Vid fabriken i Moss fick - eller rättare - erövrade operatörerna (jfr Vallas 2006 analys av arbetarnas "empowerment" i amerikanska pappers- och 
massafabriker) gradvis mer specialiserade och processpecifika kunskaper, något som ledde till att det obönhörliga hos det ekonomiska systemet blev delvis satt ur spel. Det tekniska systemet ställde efter hand krav som ledde till att en operatör svårligen lät sig ersättas av andra. På det sättet är det tekniska systemet betydligt mer medgörligt än det ekonomiska i relation till det mänskliga systemet. Det medgörliga kan betraktas som en mellanposition mellan det obönhörliga i det ekonomiska systemet och det trygghetssökande i det mänskliga systemet.

I fabriken kom detta till uttryck i att arbetarkollektivet kunde styrka sin position i förhållande till ledningen. En berättelse om detta:

Vi hade mekaniker och elektriker - för att ta det då - som hade ett ansvarsområde på fabriken som var deras. De skrev in jobb på det som skulle göras, de hämtade in fel från operatörerna, de sorterade jobben, de prioriterade dem och de tog hand om dem i samarbete med sin chef och utförde jobben utan att någon bekymrade sig om det. Det fungerade som bara den. Så kom det en ny underhållschef och han skulle ta bort den områdesansvarige. Alltså, det är så bakåtsträvande och förfärligt att det nästan gör ont att prata om det. Ta bort det som var självgående! För att markera en ändring, så skulle allt underhållsfolk sådana som elektriker och mekaniker - de skulle få arbetsuppgifter varje morgon av en förman som i samarbete med en ingenjör skulle ta reda på vad som skulle göras och göra de prioriteringarna. Det ledde ju till att saker och ting inte fungerade längre. [...] Men så kommer jag till det positiva i det här då. Men de [operatörerna] ville inte ha det på det viset, så de gjorde så som de alltid hade gjort $\mathrm{i}$ alla fall. De här grabbarna som inte hade något ansvar längre, de tog det ansvaret, eller hur? De tog det ansvaret. Och så i vartenda forum vi var i där det var nya chefer, så preciserade vi det att det fungerar för det att vi gör som vi alltid har gjort och inte som vi blir ombedda att göra. Och om någon vill jobba mot det och stoppa det, så får de fan i mig vara på jobbet tjugofyra timmar om dygnet.

En annan säger: ”Det var så pass höga krav på befattningarna efter hand att för att bli kokare - vi skämtade om att du går inte till Manpower och får dig en kokare. Det var upp till två års intern upplärning.” Vid ett tillfälle när den nya ledningen - cowboyerna - planerade en omfattande organisationsförändring blev maskinförarna på pappersavdelningen beordrade att söka sina egna jobb på nytt. Detta ignorerade de helt enkelt som en idiotisk idé från högre ort. "Vad tror de", säger en av dem, "att de ska kunna hitta ersättare där ute på gatan?" Obönhörligheten lindrades alltså av det tekniska systemets medgörlighet. 
I förlängningen härav leder också indelningen i fler system till att vi räknar med ytterligare en "roll" för den enskilde i arbetsorganisationen. Lysgaard anger tre roller: man är "anställd" i det tekniskt-ekonomiska systemet, "människa" i det mänskliga systemet och "arbetskamrat" i kollektivsystemet. Men begreppet "anställd" passar egentligen bara in i det ekonomiska systemet, inte i det tekniska; det att vara anställd handlar ju om en ekonomisk relation i förhållande till en arbetsgivare (för en detaljerad analys, se Furåker 2005). Vilken roll blir det då naturligt att ange i förhållande till det tekniska systemet? I vår ansats väljer vi att använda termen "operatör", dels för att den överensstämmer med den som används i andra studier av pappers- och massafabriker för denna tekniska roll (t.ex. Sjöström 20I3), dels för att det är det ord som de underordnade arbetarna själva använder: "Alla är operatörer. Operatörer är samlingsbegreppet." Generellt sett överensstämmer detta för övrigt med en utbredd begreppsjustering i vilken de som tidigare omtalades som industriarbetare nu betecknas som operatörer. Vi vill emellertid understryka att vår användning av ordet operatör är kopplat till det tekniska systemet. Den underordnade arbetaren fyller helt enkelt en roll som går ut på att vara operatör av ett tekniskt system när han eller hon är anställd i fabriken.

I förhållandet mellan roller och system diskuterar Lysgaard (200I, s. I27-136) även fem olika former av anslutning till ett system, som vi kort vill behandla i förbindelse med operatörsbegreppet. De fem olika formerna av systemanslutning (och detta gäller enligt Lysgaard både det tekniskt-ekonomiska systemet och kollektivsystemet; dock inte det mänskliga systemet) är "funktionell förpliktelse", "normativ förpliktelse", "självutveckling", "belöning" och "bestraffning”. Dessa kan prägla en systemmedlem i olika hög grad vid skilda tillfällen. Den funktionella förpliktelsen innebär ett åtagande gentemot det inbyggda målet $\mathrm{i}$ ett system. En funktionell förpliktelse gentemot det ekonomiska systemet rör sig exempelvis om en känsla av skyldighet hos de underordnade att bidra till organisationens omättliga strävan till att uppnå ekonomisk vinst. Den normativa förpliktelsen handlar om normer för vad som är ett passande beteende för en systemmedlem - till exempel normer för hur en god arbetskamrat bör vara enligt kollektivsystemet. Självutveckling är 
en anslutning som bygger på personliga belöningar och tillfredsställelser som individen upplever genom systemmedlemskapet. Ett exempel kan vara den trivsel och gemenskap som uppstår bland arbetskamraterna i arbetarkollektivet. De två sista - belöning och straff - är de två mest lättfattliga och innebär att anslutningen regleras genom systemets sanktioner. I förhållande till det ekonomiska systemet kan det till exempel handla om att få lön (belöning) eller få sparken (bestraffning).

När det gäller operatörens anslutning vill vi för det första lyfta fram en likhet med den anställdes koppling: Den funktionella förpliktelsen dominerar över den normativa förpliktelsen just på det sätt som enligt Lysgaard gäller för den anställde i förhållande till det tekniskt-ekonomiska systemet. Det finns exempelvis inte lika tydliga normer om hur den "goda operatören" ska vara om vi jämför med de normer som gäller för den "goda arbetskamraten". Det att vara funktionellt förpliktad gentemot det tekniska systemet är trots allt något annat än det att vara förpliktad gentemot Lysgaards tekniskt-ekonomiska system. Den funktionella förpliktelsen gentemot det tekniska systemet innebär en upplevd plikt att producera bästa möjliga kvalitet; att uppnå ett bästa möjliga resultat givet det tekniska systemets avgränsning. Samtidigt är självutveckling en central anslutning till systemet. Känslan och upplevelsen av att ha kunskaper om - och kontroll över - den teknologi som används är viktig för medlemskapet i det tekniska systemet.

Det tekniska systemets belöning och straff skiljer sig på ett intressant sätt från både det ekonomiska systemet och kollektivsystemet. Lysgaard (200I, s. I33, vår kursiv) skriver: "Belöning och straff kommer som ett resultat av andras värderingar av ens egenskaper och färdigheter, uppträdande och insats." I det tekniska systemet är det emellertid inte primärt andra som belönar och bestraffar utan den slutliga domen kommer från den opersonliga processutrustningen och produktens kvalitet. Belöningen för en god hantering av teknologin kan vara drift utan störningar och framställning av perfekta produkter; straffet för en dålig hantering kan bli driftsproblem, haveri och ansträngande underhållsarbete.

Sammanfattningsvis innebär denna uppdelning av det tekniskt-ekonomiska systemet i två separata system att vi kompletterar Lysgaards karaktäristik av det tekniskt-ekonomiska systemet som omättligt, ensidigt 
och obönhörligt, och det mänskliga systemet som begränsat, mångsidigt och trygghetssökande. Vi gör detta genom att låta Lysgaards egenskaper hos det tekniskt-ekonomiska systemet gälla bara för det ekonomiska systemet, samt genom att formulera nya karaktäristika för det tekniska systemet i det att vi kännetecknar det som avgränsat, flersidigt och medgörligt. Detta innebär också att vi specificerar ytterligare en roll för de underordnade på fabriken. I Lysgaards teori handlar det om att vara anställd i det tekniskt-ekonomiska systemet, människa i det mänskliga systemet och arbetskamrat i kollektivsystemet. Vi begränsar det att vara anställd till en relation som angår förhållanden i det ekonomiska systemet, samt kompletterar med en roll som går ut på att vara operatör i det tekniska systemet. I nästa avsnitt visar vi hur delningen i två system ger en möjlighet att lösa ett teoretiskt dilemma som har uppstått i nyare undersökningar av processindustri där Lysgaards teori har varit en central del av den analytiska ansatsen.

\section{Arbetarkollektivet infiltrerar det tekniska systemet}

I en studie av processindustri har Paavo Bergman (1995) diskuterat Lysgaards teori i relation till sina empiriska fynd och därvid framfört den analytiska slutsatsen att arbetarna där kollektivt övertar ansvaret för (delar av) produktionsprocessen. Han ger den här empiriska bilden som bakgrund till sin teoretiska argumentation: Skiftlagen inom denna typ av produktion utvecklar egna arbetskulturer utifrån den specifika kunskap som arbetet kräver och de normer och rutiner som är förknippade med den. Ett särskilt drag är att förutsättningarna för traditionella motståndsformer som produktionsbegränsning - eller med Bergmans term, "bromsning” - inte föreligger. Produktionen är alltför inriktad på samarbete och har en alltför låg grad av standardisering för att sådana strategier ska falla sig naturliga. I stället utvecklar arbetslagen egna, kollektiva sätt att genomföra arbetet och tar över arbetsuppgifter som de anser vara attraktiva. I kollektivets normer ingår att inte maska eller dra sig undan från arbetsuppgifter; normerna säger i stället att arbetarna ska ta eget ansvar för produktionen. I Bergmans analys är kollektivet därför inte begränsat till rollen som defensiv försvarare av arbetarnas ära och 
värdighet som människor, utan det är mer offensivt genom att ta ansvar för och reglera produktionsprocessen varigenom det skapar ett mått av autonomi för sina medlemmar.

I samband med en analys av stränggjutning preciserar han (1995, s. 219) sitt teoretiska bidrag så här:

Sett i ljuset av Lysgaards teori om arbetarkollektivet som ett skydd mot det tekniskt-ekonomiska systemets krav framstår det faktiska produktionsansvar som stränggjutarna tog som en involvering eller integration i detta system. Men det förefaller förhastat att tolka detta som uppslutning bakom företagets mål. Mycket talade för att det man egentligen tog ansvar för var sin "egen" anläggning och de gemensamma arbetsvillkor som var så intimt förknippade med en fungerande och störningsfri drift. Skiftlagen ville också rå sig själva och egentligen slippa all inblandning från folk "uppifrån kontoret".

Samma tanke har framförts av John Sjöström (2013) i en undersökning på ett svenskt pappersbruk. Han fann att det inte är populärt bland operatörerna att hålla på sin processpecifika kompetens som individuell kunskap, utan den måste komma kollektivet till del och bidra till dess gemensamma upprätthållande av produktionen. Han säger exempelvis (2OI3, s. IO2):

Operatörer som inte delar med sig av sin kunskap betraktas med misstänksamhet och framstår som osolidariska, både gentemot sina kollegor och gentemot det gemensamma målet att optimera processen och hålla full, störningsfri drift. Den processpecifika kompetens som utvecklas av operatörerna tillhör därför inte (enbart) individen, utan snarare kollektivet.

Både Bergman och Sjöström betonar således att ett kollektivt ansvarstagande för produktionsprocessen, vilket inkluderar en ökning och breddning av kunskapen i arbetet för operatörerna, stärker arbetarkollektivet i förhållande till det tekniskt-ekonomiska systemet. Bergman säger samtidigt explicit att det ekonomiska systemet ("företagets mål") inte är inblandat här. När han talar om arbetarnas "involvering eller integration i detta system" syftar det snarare på det tekniska systemet, särskilt en "störningsfri drift" av processerna. Detsamma gäller Sjöströms analys. Vår slutsats är därför att såväl Bergmans som Sjöströms teoretiska bidrag egentligen gäller arbetarkollektivets relation till det tekniska systemet, 
inte det ekonomiska - även om båda talar om det tekniskt-ekonomiska systemet som en enhet.

I Lysgaards analys skulle slutsatsen att delar av det tekniskt-ekonomiska systemet tas över av arbetarkollektivet vara en orimlighet. Han diskuterar (200I, s. I72-I85; kapitel 7) en utveckling där det teknisktekonomiska systemet infiltrerar kollektivet som en reell möjlighet, men menar att den omvända processen inte är tänkbar. Kollektivet kan inte infiltrera det tekniskt-ekonomiska systemet - det skulle i stället innebära att kollektivet försvagas och det tekniskt-ekonomiska systemet stärks. Hans utgångspunkt är att systemen har varsitt idealtillstånd, som för det tekniskt-ekonomiska systemet innebär att det kommunicerar direkt med varje anställd som individ medan motsvarande tillstånd för kollektivsystemet är att all kommunikation går via kollektivet. Hans fortsatta argumentation handlar om hur kollektivsystemets styrka i att uppnå sitt idealtillstånd kan variera medan det tekniskt-ekonomiska systemets styrka förblir konstant. Det är också viktigt att notera att i analysen är det tekniskt-ekonomiska systemet alltid primärt och kollektivsystemet sekundärt i förhållande till detta. Slutsatsen härav är att "det inte finns någon form av samexistens [mellan systemen] som går ut på en bestående bortkoppling av det tekniskt-ekonomiska systemet" (200I, s. I76). Man kan teoretiskt tänka sig att kollektivet med hjälp av makt tränger in på det tekniskt-ekonomiska systemets område eller rent av tar över det, men en sådan utveckling skulle inte innebära någon principiell förändring i det tekniskt-ekonomiska systemets position som primärt system i arbetsorganisationen. Det kan aldrig elimineras med mindre än att arbetsplatsen som sådan läggs ned. Det sekundära arbetarkollektivet kan däremot varaktigt elimineras på det här sättet: Om kollektivet lyckas göra ett maktövertagande av det tekniskt-ekonomiska systemet blir det självt en ny företagsledning - en ny representant för det tekniskt-ekonomiska systemet. I den mån arbetarkollektivet infiltrerar det tekniskt-ekonomiska systemet blir det bara en del av detta system. Inget maktskifte sker.

Det tekniskt-ekonomiska systemet kan infiltrera kollektivsystemet genom att tränga in på områden som det ligger i kollektivets intresse att ha kontroll över. Förutsättningen är dock att det senare är svagt och 
Lysgaard diskuterar utförligt hur sådan infiltration kan gå till samt uppställer en rik samling hypoteser om under vilka villkor kollektivet tenderar att bli svagt respektive starkt. Men den processen att kollektivet skulle kunna infiltrera det tekniskt-ekonomiska systemet är alltså utesluten enligt Lysgaards teori om arbetarkollektivet. En sådan infiltration skulle bara stärka det tekniskt-ekonomiska systemet på arbetarkollektivets bekostnad.

Vi står således inför en teoretisk motsättning: Bergman och Sjöström hävdar empiriskt att arbetarkollektivet faktiskt infiltrerar det teknisktekonomiska systemet, medan Lysgaard säger att något sådant är teoretiskt uteslutet, eftersom det bara skulle innebära att kollektivet uppgår i detta system och därmed sätts ur spel. Hur ska vi förstå denna motsättning? Kan vi lösa upp den på något sätt? En första iakttagelse är att såväl Bergman och Sjöström som Lysgaard resonerar utifrån begreppet "tekniskt-ekonomiskt system". Bergmans och Sjöströms argumentation berör dock egentligen bara det tekniska systemet med det ekonomiska orört och i full funktion. Och granskar vi Lysgaards argumentation närmare finner vi att han egentligen bara berör det ekonomiska systemet med det tekniska orört och i full funktion. Det visar sig till exempel i att den enda direkta empiriska jämförelse han gör är mellan det ekonomiska systemet i det kapitalistiska USA respektive det kommunistiska Sovjetunionen (200I, s. 177). När Lysgaard diskuterar kollektivets inverkan på det tekniskt-ekonomiska systemet analyserar han i praktiken bara det ekonomiska systemet och när Bergman och Sjöström diskuterar samma sak analyserar de i praktiken bara det tekniska systemet. Det är därför de kommer till skilda slutsatser. Finns någon lösning på detta teoretiska dilemma?

Vårt analytiska steg att skilja det tekniska och det ekonomiska systemet åt öppnar för en begreppslig utveckling som gör det möjligt att överkomma denna teoretiska motsättning: Kollektivets relation till det tekniskt-ekonomiska systemet kan tänkas vara olika när det gäller vart och ett av dessa system. Det vi funnit empiriskt är en process som medfört att kollektivet infiltrerat - för att använda Lysgaards term - det tekniska systemet medan det ekonomiska systemet lämnats orört. Det finns redan i Lysgaards egna empiriska material antydningar som går att tolka 
i den riktningen. Han återger en samling intervjucitat (200I, s. I54-I55) som han säger handlar om att arbetarna betonar sina "kollektiva bidrag till det tekniskt-ekonomiska systemet”. Om vi studerar dem närmare märker vi att de mest handlar om bidragen till det tekniska systemet, även om det ekonomiska nämns marginellt:

Förmannen behöver inte springa och ta beslut när det gäller maskinen. De gamla vid maskinen vet bäst vad som ska göras.

Ofta förstår vi ju sakerna bättre än förmannen.

När de pratar om "experter", så måste man komma ihåg att det är de som kör [maskinerna] som är experter.

Det sades en gång att ni har inte betalt för att tänka - det är det ingenjörerna som har betalt för. Men grabbarna här tänker en massa mer än ingenjörerna någon gång har gjort.

Produktionen skulle nog öka minst en 30-50 procent om de lyssnade på oss.

Dessvärre blir vi inte tillfrågade tillräckligt om nya saker på förhand. En man som har hållit på med en maskin i trettio år har bättre insikt och förståelse än till och med en ingenjör. Det skulle löna sig att rådgöra med dem som ska ha hand om maskinerna. Och det skulle vi värdesätta. Vi vill gärna ha bättre arbetsförhållanden och bra maskiner här på verkstan.

Utan att Lysgaard förefaller observera det gör hans intervjupersoner implicit en distinktion mellan de två systemen och riktar i första hand sin uppmärksamhet mot sina bidrag till det tekniska systemet.

Detta drag är även tydligt i våra intervjuer. De som över huvud taget tar upp frågan om ekonomin lämnar den till ägarna och accepterar att lönsamhet är nödvändig för att fabriken ska kunna finnas kvar. Operatörerna menar att fabriken måste gå med viss vinst eftersom det är viktigt för underhållet av maskinparken och för att kunna investera i ny teknik, något som anses vara lovvärt. Däremot betraktas det som förkastligt att ta ut vinst på bekostnad av underhåll och teknologiska investeringar, vilket särskilt visade sig i intervjuerna apropå "cowboyerna", det vill säga de nya ägarna från 2006: 
Det upplevde inte bara jag men väldigt många som smärtfyllt. [...] Det var lite mer profithungrigt, för då var det liksom snack om att dra ut mesta möjliga. För det var inte snack om några investeringar och vi förstod ju det efter hand att här ska de suga ut de sista dropparna.

De hade inte pengar till att underhålla tillräckligt. Och då förföll det mer och mer här och där, och vi slet för att få saker och ting att gå ordentligt. Så det var en ond cirkel och mycket frustration i omlopp.

De tog pengarna och underhållet fick lida. Det blev inte investerat i något nytt.

De såg väl mer efter egen profit än att utveckla koncernen.

Det händer även att operatörerna framför samma synsätt på sin egen betydelse i det tekniska systemet som arbetarna gjorde på Lysgaards tid och som också rapporterats av Bergman och Sjöström:

Det var en som började här, en ingenjör, och honom måste jag jaga ut en gång. Jag blev förbannad. För han skulle komma och lära mig jobbet, men jag hade ju varit här i många år. För han skulle börja och förklara vad jag skulle göra, och var lite påstridig. Och då blev jag arg och jagade ut honom. [...] När jag hade lugnat ner mig, så ropade jag på honom och bad honom komma upp. Och då sa han, jag trodde inte du kunde bli så ilsk, jag. Då sa jag, du måste ju begripa det att du kan inte komma här - du har inte någon aning om det här du, och så ska du komma här och lära mig det jag har hållit på med i många år. Kom och fråga, så kan vi diskutera, kom inte och peka och säg att jag ska göra si eller så. Det går inte an, för detta begriper du ingenting av. Och det gjorde han inte, men han skulle liksom visa vem han var.

Vi kan nu se detta som att operatören försvarar sin position i det tekniska systemet och sitt ansvar för sina arbetsuppgifter mot det han uppfattar som ett försök till infiltration från en överordnad. En mer erfaren ingenjör säger om sin relation till operatörerna: "Jag är väldigt försiktig, vet vad de accepterar, det har jag lärt mig."

Men i våra data finns även en helt annan syn på ingenjörernas och andra överordnades kunskap än den som Lysgaard redovisar och som citatet ovan ger uttryck för. Där visas en respekt för denna kunskap och det framkommer att olika tekniska problem är föremål för konsultationer och diskussioner mellan främst operatörer och ingenjörer. Hur kommer sig denna förändring i synsätt på teoretisk kunskap om produktions- 
processen som uppenbarligen ägt rum sedan Lysgaards undersökning? Vår förklaring är att operatörernas respekt för denna form av kunskap har växt i takt med att de själva har gått omfattande utbildningar för att kunna bemästra sitt eget arbete. Det medför i sin tur att de även värdesätter ingenjörernas abstrakta kunskap i betydligt högre grad än på Lysgaards tid. Samtidigt ligger i detta att arbetarkollektivet framgångsrikt har infiltrerat det tekniska systemet, varav en omfattande utbildningsverksamhet på fabriken är en viktig del. Kunskap - och därmed utbildning - ingår ju som en del av den definition av teknologi som vi har angett tidigare.

Redan på 1970- och 1980-talen drevs utbildning för lärlingar i fabrikens regi, samtidigt som det bildades ett upplärningsråd med representanter för operatörerna och ingenjörerna. Operatörerna var inte särskilt nöjda med utbildningen vare sig för lärlingarna eller för egen del. En av de informella ledarna för arbetarkollektivet, som också var representant för operatörerna i upplärningsrådet, erbjöd sig därför att utarbeta principer för lärlingar inom en produktionsavdelning, i första omgången begränsat till blekeriet. Upplägget gick ut på att utbildningen lades upp i faser om cirka en vecka med tester i varje fas och som avslutning. Godkänt på alla tester krävdes för att självständigt få köra relevant del av anläggningen. Utbildningsplanen enligt dessa riktlinjer började tillämpas, den blev framgångsrik och spreds till resten av fabriken.

Samtidigt var operatörerna alltså inte särskilt nöjda med sin egen utbildning. Olika skift körde processen på sitt eget sätt, vilket bland annat ledde till problem om en operatör skulle byta skift eller tillfälligt ersätta någon på ett annat skift. Även risken för fel i produktionsprocessen ökade. Missnöjet resulterade i att operatörerna började tillämpa samma typ av utbildning även för egen del från 1990 och framåt - en utbildning som de alltså drev själva. Formellt skulle driftsingenjören godkänna upplägg och faser, men innehållet utarbetades av operatörerna utifrån egen erfarenhet, leverantörsbeskrivningar av maskinparken, flytscheman och driftsinstruktioner. Kollektivet tog på detta sätt initiativet och samarbetade sedan med processingenjörer, det vill säga de närmast ansvariga inom ledningen för det tekniska systemet, medan högsta ledningen inte var inblandad (jfr Holsvik 20I5, s. I3). Inte heller facket 
var direkt involverat, men dess ledare var positiva till utbildningen. Varje avdelning fick en operatör som var utbildningsansvarig för programmen och testerna. Särskilda instruktioner sammanställdes för varje anlägg, vilket en ansvarig operatör berättar om:

Alltså i utgångspunkten så var det leverantören som hade en instruktion om hur anlägget skulle köras, men den var ju väldigt kortfattad och dålig. Och det var heller inte driftsingenjören som satte sig ned och gjorde en instruktion. Alla [operatörer] som var i närheten av anlägget kallades in och fick bidra med sina erfarenheter.

Efter hand blev utbildningarna mycket omfattande. Det här uttalandet gäller fiberanlägget:

Som regel, när du började, så var det som fältoperatör där du lärde dig att gå rundan och ta prover och sådant, därefter kom du gärna till sileriet som var ett lite enklare anlägg att köra, det krävdes inte så mycket för att behärska silningen, det var mer transport, så började du på kokeriet efteråt. Så för att bli erfaren operatör i fiber, så var det i varje fall 5 års upplärning.

Denna avancerade utbildning var och förblev en angelägenhet för arbetarkollektivet och dess medlemmar såg framför allt två fördelar med den. Den ena var att den förbättrade deras arbetsmiljö genom att göra arbetsuppgifterna mer intressanta och omväxlande, det "blev helt normalt att folk kunde både två och tre anlägg och roterade mellan dem" (Grønna 20I4, s. 74). En operatör ger den här konkreta beskrivningen från pappersfabriken av hur detta kunde gå till:

Förr så hade vi ju torkare och maskinförare och så. De sista åren [innan konkursen] så hade vi processansvariga. Den processansvarige, han styrde allt med processen han, inklusive tork, inte sant. Och så hade vi fältoperatör, och han hade väldigt lite med pc:n att göra. Och så kunde de byta, och så kunde han den andre vara processansvarig den andra veckan och fältoperatör. De bytte, eller hur? På det sättet rullade vi det.

"Vi” i citatet står för operatörerna på avdelningen, inte förmän, ingenjörer eller andra delar av ledningen. Eller som en förman sa: "Det styrde vi inte, för det lät vi grabbarna styra själva.” En annan sådan berättelse om upplärningsprogrammet och dess konsekvenser: 
Så nere i kokeriet, där kunde i stort sett alla - alla kunde alla jobben i kokeriet sådär efter hand. Där nere så var fältoperatören, det var liksom det första, för det var ute i hela anlägget och du skulle kunna motorer och ventiler och pumpar och allt, veta var de stod och allt sådant. Så du visste om det skedde ett eller annat så skulle du inte börja gräva och fundera på var i all världen är den där. Så där var det väldigt mycket lokalkunskap. Det var det första de lärde sig. Och när de hade gått som fältoperatör en god stund, så blev det som regel att lära kokaren, och så kom då indunstaren efter hand.

Om den första fördelen med utbildningen var att den medförde en bättre arbetsmiljö, så var den andra fördelen att produktionsprocessen förbättrades, eftersom den ökade kvalifikationsnivån medförde att processen kunde gå jämnare med färre fel. Operatörerna tog ett allt större ansvar för det tekniska systemet och försökte hela tiden göra det bättre - något som även ökade intresset för arbetet. En operatör sa så här om detta:

Jag gillade att köra anlägget, sitta och köra kokaren, följa med och vara med och utveckla det där, det tyckte jag var ett väldigt spännande jobb. Med trendsystemet så kunde du följa med och ta reda på sammanhang, det var ju så spännande. [...] Plus att du känner att du har inflytande på din egen situation, det är inte minst viktigt. Och det kände vi på många sätt att vi fick mer och mer inflytande genom att vi själva visade intresse för att utveckla jobben, och att se här - här finns det nya sätt att jobba på och organisera på.

Detta byggde på att den nya tekniken gjorde det möjligt för arbetarkollektivet att utöka sin kontroll över produktionen, det vill säga infiltrera det tekniska systemet. Den teoretiska utgångspunkten är att det tekniska systemet innehåller såväl möjligheter som begränsningar för både arbetarkollektivet och ledningen (jfr Bélanger 2006) och att kollektivet vid det här tillfället var effektivt när det gäller att hantera dess avgränsade, flersidiga och medgörliga karaktär. Det blev lättare att ändra och justera ingreppen på ett sådant sätt att processen optimerades. Särskilt möjligheten att analysera trender i produktionen genom datasystemet bidrog i hög grad till att öka operatörernas kunskap om processen. Här ett exempel från lutkokeriet:

Efter hand som trendanalysen kom fram i lutkokeriet och vi fick datastyrda system och kunde bygga våra egna trendsystem så hjälpte det väldigt. [...] När det blev datareglering i lutkokeriet kunde vi se på reaktionstemperaturerna för 
indunstaren, till exempel, som parameter och lägga på kalkdosering som en parameter, och grönlutsmängd in, så vi kunde se hela sammanhanget på en bild. Förr satt vi där och gissade - jag lägger på lite, jag tar av lite, ändrar lite temperatur där, så sker det något, så tror jag att det leder till något bättre här borta, men nu kunde du se det. Så hade vi de kemiska analyserna och så trendanalyserna och - OK - "4 timmar sedan sista ändringen, nu börjar kurvan på analysen". Då kunde vi systematisera och köra processen mer optimalt.

Förutsättningen här var naturligtvis att arbetarkollektivets infiltration av det tekniska systemet innefattade att operatörerna själva tog ansvar för produktionen - till och med i sådan utsträckning att de kunde hoppa in på sin lediga tid om det krävdes. En av reparatörerna sa så här när han efter nedläggningen såg tillbaka på denna aspekt av arbetet på fabriken:

Du skulle inte använda för lång tid på att lösa problemet själv, så om du inte förstod det så var det bara att ringa. Det som var viktigt, var att maskinen stod så kort stund som möjligt. Och då var det väldigt god sammanhållning för det att den goda kollegan du ringde då för att hjälpa dig, han svarade "Ja, jag kommer och hjälper dig" - fredagskväll eller lördagskväll, "Ja, jag kommer". Och nästa gång var det kanske han som var i din situation och ringde dig, så visste du att han hade hjälpt dig förra gången så sa du inte nej till honom. Det var sådan sammanhållning.

Det ledde också till att allt intensivare diskussioner och faktiska experiment för att förbättra driften av det tekniska systemet förekom över hela fabriken. Det förhållandet att de processkunniga operatörerna nu själva kunde göra trendanalyser av information från datasystemet för att se om processen löpte som den skulle var särskilt viktig. En av dem återger en sådan händelse (Grønna 20I4, s. 74):

En gång fann jag klara signaler på att rörsilarna i inmatningen på kokaren hade för liten kapacitet. När det kollades närmare, visade det sig att det satts in silar med för liten öppning för flera år sedan. Genom att byta till riktiga silar kunde vi öka produktionen och undgå stopp.

Operatörerna behärskade nu upp till tre befattningar, vilket medförde att de kunde rotera mellan dessa allteftersom de blev certifierade till att köra dem. Medan den tidigare tekniken var liktydig med att arbetsrotering betydde ytterligare belastning för operatörerna, öppnade den ökade automatiseringen för att kollektivet kunde ta över produktionsprocessen. 
Operatörernas kontroll över arbetet ökade och kollektivet infiltrerade det tekniska systemet.

\section{Slutsatser}

Bakgrunden till den teoretiska argumentation vi fört är dubbel. För det första bygger den på empiriska analyser av produktionens och arbetets utveckling på den fabrik som Lysgaard genomförde sin undersökning på, massa- och pappersfabriken Peterson \& Sønn i Moss (Karlsson, Skorstad \& Axelsson 20I5). Vi utgick därvid från förändringar i de tre betingelser för arbetarkollektivet som Lysgaards teori innehåller, nämligen problemtolkning, interaktion och identifikation, och vilka konsekvenser dessa fått för arbetarkollektivet under 1950-talet, 1980-talet och 2010talet. För det andra har vi hävdat att teorin om arbetarkollektivet står sig mycket väl vid en jämförelse med dagens anglosaxiska teorier om kollektiv och motstånd på arbetsplatser, såsom teorier om kollektivism, de anställdas kollektiv och självorganisation (Karlsson 20I5; Skorstad \& Karlsson 2017). Vidare är vår argumentation ett förslag för att lösa den teoretiska motsättning som uppstått i senare forskning i anslutning till Lysgaards teori. Såväl Bergman (1995) som Sjöström (2013) har i sina undersökningar av processindustri respektive pappersbruk funnit ett empiriskt mönster som går ut på att arbetarna tar ansvar för alltmer av produktionsprocessen och tolkat detta som att kollektivet infiltrerar det tekniskt-ekonomiska systemet. Problemet är att en sådan utveckling inte är möjlig enligt Lysgaard, den skulle bara innebära att kollektivet blir en ny representant för det tekniskt-ekonomiska systemet.

Förslaget till lösning går ut på att Lysgaards teoretiska enhet det "tekniskt-ekonomiska systemet" kan delas upp i två enheter, dels ett "ekonomiskt system", dels ett "tekniskt system". Vi menar att vi med detta kan överskrida den teoretiska motsättningen, eftersom den bygger på att Bergman och Sjöström egentligen bara tar hänsyn till det tekniska systemet och Lysgaard enbart det ekonomiska. I vår uppföljningsstudie har vi därmed kunnat genomföra analysen på det sättet att arbetarkollektivet har infiltrerat det tekniska systemet men inte gjort några ansträngningar att infiltrera det ekonomiska systemet. Det sista kunde 
teoretiskt ha tagit sig uttryck i att kollektivet krävt ökat inflytande över den ekonomiska planeringen - vilket inte var fallet, krav på inflytande gällde enbart det tekniska systemet. I sista hand kunde det ha handlat om ansträngningar i samband med nedläggningen att ta över fabriken och driva den i kooperativ form - något som över huvud taget inte nämndes.

I vårt resonemang lämnar vi därför det ekonomiska systemet därhän (åtminstone tillsvidare) till förmån för att komplettera Lysgaards teori med ett par specifikationer av det tekniska systemet. Vår poäng i det sammanhanget är att de karaktäristika som Lysgaard tilldelar det tekniskt-ekonomiska systemet egentligen passar bäst in på det ekonomiska systemet, medan vi funnit nya särdrag för det tekniska systemet. Vi får således en uppställning där det ekonomiska systemets ensidiga, omättliga och obönhörliga krav står mot det mänskliga systemets kännetecken att vara mångsidigt, begränsat och trygghetssökande. Vi finner samtidigt att det tekniska systemet är mindre hotande mot de mänskliga dragen än det ekonomiska systemet. Vi klassificerar det som flersidigt, avgränsat och medgörligt. Flersidigt betyder att kraven inte är ensidiga utan kan skifta beroende på kontext; avgränsat innebär att det inte är obegränsat utan att det finns en övre och en undre gräns för vad det kräver; och medgörligt står för att det inte är obönhörligt utan kan påverkas av de arbetande. Härigenom placerar vi det tekniska systemets krav någonstans mellan kraven från det ekonomiska respektive det mänskliga systemets karaktäristika.

Uppdelningen i två system får också till konsekvens att vi kan införa en ny roll bland de underordnade. Enligt Lysgaards teori finns tre sådana roller genom att arbetaren är anställd i det tekniskt-ekonomiska systemet, människa i det mänskliga systemet och arbetskamrat i kollektivsystemet. Genom vår begreppsliga utveckling av teorin begränsas att vara anställd till en roll i det ekonomiska systemet, medan den roll vi tillför är att vara operatör i det tekniska systemet. 


\section{Referenser}

Ackroyd, S. \& J. C. Karlsson (20I4) "Critical realism, research techniques, and research designs", i P. Edwards, J. O’Mahoney \& S. Vincent (red.) Studying organizations using critical realism. A practical guide (s. 2I-45). Oxford: Oxford University Press.

Axelsson, J., J. C. Karlsson \& E. J. Skorstad (2019) Collective mobilization in changing conditions. Worker collectivity in a turbulent age. Basingstoke: Palgrave Macmillan.

Bélanger, J. (2006) "Technology and work", i M. Korczynski, R. Hodson \& P. Edwards (red.) Social theory at work (s. 325-355). Oxford: Oxford University Press.

Bergman, P. (1995) Moderna lagarbeten. Studier av arbete, teknik och organisation i högteknologisk processindustri. Lund: Arkiv förlag.

Blauner, R. (1964) Alienation and freedom. The factory worker and his industry. Chicago: Chicago University Press.

Furåker, B. (2005) Sociological perspectives on labor markets. Basingstoke: Palgrave Macmillan.

Grønna, B. A. (20I4) Et arbeidsliv på Cellulosen. Rælingen: Flisby’n.

Holsvik, B. (2015) "Den fleksible operatør. Omstilling, opplæring og fleksibilitet ved Peterson Moss 1990-2006", i Arbeiderhistorie 2015. Tema: Det fleksible arbeidsliv (s. II3-I34). Oslo: LO Media.

Karlsson, J. C. (2015) "Lysgaard i Anglosaxien - en jämförande tankelek", Arbetsmarknad \& Arbetsliv, 21, I: 7-23.

URL: https://journals.lub.lu.se/aoa/article/view/I764I (20 december 20I8)

Karlsson, J. C. \& A. Bergman (2017) Methods for social theory. Analytical tools for theorizing and writing. London: Routledge.

Karlsson, J. C. \& E. J. Skorstad (2019) "Arbetarkollektivets skilda motståndsformer", i Å. Sandberg (red.) Arbete \& välfärd. Ledning, personal och organisationsmodeller i Sverige (s. 519-534). Lund: Studentlitteratur.

Karlsson, J. C., E. J. Skorstad \& J. Axelsson (2015) "On the track of the worker collectivity: Its various adventures over the past 60 years", Sage Open, april-juni: I-I3. DOI: https://doi.org/IO.II77/21582440I5575635

Lysgaard, S. (200I [196I]) Arbeiderkollektivet. En studie i de underordnedes sosiologi. Oslo: Universitetsforlaget.

Maxwell, J. A. (2012) A realist approach for qualitative research. London: SAGE.

Perrow, C. (1999) Normal accidents. Living with high-risk technologies. Princeton: Princeton University Press.

Saldaña, J. (2013) The coding manual for qualitative researchers. London: SAGE.

Sjöström, J. (2013) Det komplexa deltagandet. Praktikgemenskaper, kunskapsprocesser och arbetsmiljöarbete vid ett pappersbruk. Linköping: Linköpings universitet.

Skorstad, E. J. (1987) Teknologi og arbeid. Trondheim: NTNU.

Skorstad, E. J. (2002) Organisasjonsformer. Kontinuitet eller forandring? Oslo: Gyldendal akademisk.

Skorstad, E. J. \& J. C. Karlsson (2017) "The worker collectivity and Anglo-Saxon theories of collectivity", Economic and Industrial Democracy, förhandspublisering 24 
AXELSSON, KARLSSON \& SKORSTAD | ARBETARKOLLEKTIVET I DAG

augusti 2017 .

DOI: https://doi.org/IO.II77/OI4383IXI7713115

Vallas, S. P. (2006) "Empowerment redux: structure, agency, and the remaking of managerial authority", American Journal of Sociology, III, 6: 1677-1717. DOI: https://doi.org/10.1086/499909

Zuboff, S. (1988) In the age of the smart machine. The future of work and power. New York: Basic Books. 


\section{Begreppet arbete}

\section{Definitioner, ideologier} och sociala former

\section{Jan Ch Karlsson}

Vad är "arbete"? Som abstrakt begrepp formulerades det med den begynnande kapitalismen, men fick snart så många innebörder att få verkligen visste vad det stod för. Jan Ch Karlsson, professor i sociologi med en lång karriär som forskare i arbetsvetenskap, analyserar i sin numera klassiska avhandling hur arbetsbegreppet använts inom samhällsvetenskapen och visar på produktiva vägar framåt.

"Läs mer om boken på www.arkiv.nu» 